\title{
Oral Semaglutide, A New Option in the Management of Type 2 Diabetes Mellitus: A Narrative Review
}

Areti Sofogianni · Konstantinos Tziomalos (D)

Received: July 1, 2020 / Published online: September 4, 2020

(C) The Author(s) 2020

\section{ABSTRACT}

According to current guidelines, glucagon-like peptide-1 (GLP-1) receptor agonists are the antidiabetic agent of choice in patients with type 2 diabetes mellitus (T2DM) and established cardiovascular disease (CVD) and are also the preferable antidiabetic agent in patients with T2DM without CVD but with indicators of high cardiovascular risk. A limitation in the use of GLP-1 receptor agonists is that they are delivered by subcutaneous injections. In this context, the development of an orally administered formulation of semaglutide offers an additional option in the management of patients with T2DM. In the present review, we discuss the findings of the main trials that evaluated the safety and efficacy of oral semaglutide. Oral semaglutide appears to be more effective in reducing $\mathrm{HbA}_{1 \mathrm{c}}$ levels and body weight than other antidiabetic agents and similarly effective to other GLP-1 receptor agonists. The safety profile of oral semaglutide is also comparable with other members of its class. Even though oral semaglutide did not reduce the incidence of

Digital Features To view digital features for this article go to https://doi.org/10.6084/m9.figshare.12800660.

A. Sofogianni $\cdot$ K. Tziomalos $(\varangle)$

First Propedeutic Department of Internal Medicine,

Medical School, AHEPA Hospital, Aristotle

University of Thessaloniki, Thessaloniki, Greece

e-mail: ktziomalos@yahoo.com the composite primary endpoint in a randomized controlled trial, a reduction in cardiovascular and all-cause mortality was observed. Therefore, oral semaglutide appears to represent a useful tool in the management of patients with TD2M, particularly those with established CVD or high cardiovascular risk and unwilling to receive injectable GLP-1 receptor agonists.

Keywords: Cardiovascular disease; Glucagonlike peptide-1 receptor agonists; Oral semaglutide; Type 2 diabetes mellitus; Weight

\section{Key Summary Points}

Oral semaglutide reduces $\mathrm{HbA}_{1 \mathrm{c}}$ and body weight more than other oral antidiabetic agents

Oral semaglutide induces comparable reductions in $\mathrm{HbA}_{1 \mathrm{c}}$ and body weight with injectable glucagon-like peptide-1 receptor agonists

The safety profile of oral semaglutide is also similar with injectable glucagon-like peptide-1 receptor agonists 


\section{INTRODUCTION}

According to current guidelines, glucagon-like peptide-1 (GLP-1) receptor agonists are the antidiabetic agent of choice in patients with type 2 diabetes mellitus (T2DM) and established cardiovascular disease (CVD) [1]. Moreover, GLP-1 receptor agonists are also the preferable antidiabetic agent in patients with T2DM without CVD but with indicators of high cardiovascular risk, including age $\geq 55$ years, coronary, carotid or lower extremity artery stenosis $>50 \%$, left ventricular hypertrophy, estimated glomerular filtration rate (GFR) $<60 \mathrm{ml} / \mathrm{min} / 1.73 \mathrm{~m}^{2}$ or albuminuria [1]. Notably, these agents should be considered independently of the baseline $\mathrm{HbA}_{1 \mathrm{c}}$ levels and $\mathrm{HbA}_{1 \mathrm{c}}$ target [1]. Large randomized controlled trials showed that once-daily liraglutide as well as once-weekly semaglutide and dulaglutide reduce cardiovascular morbidity in patients with T2DM and increased cardiovascular risk [2-4].

A limitation in the use of GLP-1 receptor agonists is that they are delivered by subcutaneous injections. In this context, the development of an orally administered formulation of semaglutide offers an additional option in the management of patients with T2DM. In the present review, we discuss the findings of the main trials that evaluated the safety and efficacy of oral semaglutide as well as the effects of this agent on cardiovascular outcomes and its costeffectiveness.

\section{METHODS}

The PubMed database was reviewed for papers published up to June 2020 using the terms "diabetes," "glucagon-like peptide-1 receptor agonists" and "oral semaglutide." The references of pertinent articles were also hand-searched for relevant papers. Only studies published in English were considered. This article is based on previously conducted studies and does not contain any studies with human participants or animals performed by any of the authors.

\section{PHARMACOLOGY OF ORAL SEMAGLUTIDE}

Oral semaglutide is coformulated with the absorption enhancer sodium $\mathrm{N}$-[8-(2-hydroxybenzoyl) aminocaprylate] (SNAC) $[5,6]$. SNAC has been shown to be safe [6-8]. It has been proposed that SNAC increases $\mathrm{pH}$ around the tablet, thus protecting semaglutide from degradation by pepsin and by the acidic gastric $\mathrm{pH}$ [5]. Moreover, SNAC appears to promote the formation of semaglutide monomers, which are more easily absorbed [5]. Furthermore, SNAC enhances the absorption of semaglutide by inducing membrane fluidization and surface epithelial sloughing in the gastric mucosa [5]. Coadministration of semaglutide with lisinopril, digoxin and warfarin in healthy subjects did not affect the area under the plasma concentration-time curve and the maximum plasma concentration of the latter medications [9]. On the other hand, the plasma concentration-time curve of metformin increased by $32 \%$ when coadminstered with semaglutide, whereas its maximum plasma concentration did not change [9]. However, this increase in exposure to metformin does not appear to be clinically relevant [9]. In another study, coadministration of omeprazole did not affect the plasma concentration-time curve and maximum plasma concentration of semaglutide [10]. Food intake reduces the absorption of semaglutide, and therefore patients must wait $30 \mathrm{~min}$ before eating after taking semaglutide [8]. Impairment of hepatic or renal function does not appear to affect the pharmacokinetics of semaglutide $[11,12]$.

The Peptide InnOvatioN for Early DiabEtes Treatment (PIONEER) program compared the safety and efficacy of semaglutide with placebo as well as with other oral and injectable antidiabetic agents (Table 1).

\section{Oral Semaglutide Compared with Placebo}

In the PIONEER-1 trial, 703 patients with T2DM managed by diet and exercise alone were randomized to receive once-daily oral semaglutide 3,7 or $14 \mathrm{mg}$ or placebo for 26 weeks [13]. 
Table 1 Major studies that evaluated the safety and efficacy of oral semaglutide

\begin{tabular}{|c|c|c|c|c|c|c|c|}
\hline Study & Ref & $n$ & $\begin{array}{l}\text { Follow- } \\
\text { up } \\
\text { (weeks) }\end{array}$ & Baseline treatment & $\begin{array}{l}\text { Comparator } \\
\text { drug }\end{array}$ & $\begin{array}{l}\text { Dosage of } \\
\text { semaglutide }\end{array}$ & Major findings \\
\hline $\begin{array}{l}\text { PIONEER- } \\
1\end{array}$ & 13 & 703 & 26 & $\begin{array}{l}\text { Diet and exercise } \\
\text { alone }\end{array}$ & & $\begin{array}{l}3,7 \text { or } \\
14 \mathrm{mg} / \text { day }\end{array}$ & $\begin{array}{l}\text { Semaglutide reduced } \mathrm{HbA}_{1 \mathrm{c}} \\
\text { and weight by } 0.7-1.4 \% \text { and } \\
0.2-2.6 \mathrm{~kg} \text { more than } \\
\text { placebo, respectively } \\
\text { Treatment discontinuation: } \\
2.3-7.4 \% \text { and } 2.2 \% \text {, } \\
\text { respectively }\end{array}$ \\
\hline $\begin{array}{l}\text { PIONEER- } \\
8\end{array}$ & 18 & 731 & 52 & $\begin{array}{l}\text { Insulin with or } \\
\text { without } \\
\text { metformin }\end{array}$ & & $\begin{array}{l}3,7 \text { or } \\
14 \mathrm{mg} / \text { day }\end{array}$ & $\begin{array}{l}\text { Semaglutide reduced } \mathrm{HbA}_{1 \mathrm{c}} \\
\text { and weight by } 0.5-1.2 \% \text { and } \\
0.9-3.3 \mathrm{~kg} \text { more than } \\
\text { placebo, respectively } \\
\text { Nausea: } 1.6-3.3 \text { times more } \\
\text { frequent in the semaglutide } \\
\text { arm }\end{array}$ \\
\hline $\begin{array}{l}\text { PIONEER- } \\
7\end{array}$ & 14 & 504 & 52 & $\begin{array}{l}\text { 1-2 oral } \\
\text { antidiabetic agents }\end{array}$ & $\begin{array}{l}\text { Sitagliptin } \\
100 \mathrm{mg} / \text { day }\end{array}$ & $\begin{array}{l}3,7 \text { or } \\
14 \mathrm{mg} / \text { day }\end{array}$ & $\begin{array}{l}\text { More patients achieved } \mathrm{HbA}_{1 \mathrm{c}} \\
\text { levels }<7 \% \text { in the } \\
\text { semaglutide group ( } 63 \mathrm{vs.} \\
28 \% \text { in the sitagliptin group) } \\
\text { and mean weight loss was } \\
2.2 \mathrm{~kg} \text { greater in the former }\end{array}$ \\
\hline $\begin{array}{l}\text { PIONEER- } \\
3\end{array}$ & 16 & 1864 & 78 & $\begin{array}{l}\text { Metformin with or } \\
\text { without } \\
\text { sulfonylurea }\end{array}$ & $\begin{array}{l}\text { Sitagliptin } \\
100 \mathrm{mg} / \text { day }\end{array}$ & $\begin{array}{l}3,7 \text { or } \\
14 \mathrm{mg} / \text { day }\end{array}$ & $\begin{array}{l}\text { Semaglutide } 7 \text { and } 14 \mathrm{mg} / \text { day } \\
\text { reduced } \mathrm{HbA}_{1 \mathrm{c}} \text { and weight } \\
\text { more than sitagliptin (by } 0.3 \\
\text { and } 0.7 \% \text {, respectively, and } \\
\text { by } 1.6 \text { and } 2.4 \mathrm{~kg} \text {, } \\
\text { respectively) } \\
\text { Treatment discontinuation } \\
\text { rates: } 15.0,19.1 \text { and } 13.1 \% \text {, } \\
\text { respectively }\end{array}$ \\
\hline $\begin{array}{l}\text { PIONEER- } \\
2\end{array}$ & 17 & 822 & 52 & Metformin & $\begin{array}{c}\text { Empagliflozin } \\
25 \mathrm{mg} / \text { day }\end{array}$ & $14 \mathrm{mg} /$ day & $\begin{array}{l}\text { Semaglutide reduced } \mathrm{HbA}_{1 \mathrm{c}} \\
\text { and body weight by } 0.4 \% \\
\text { and } 0.9 \mathrm{~kg} \text { more than } \\
\text { empaglifozin, respectively } \\
\text { Gastrointestinal adverse events } \\
\text { were more common with } \\
\text { semaglutide }\end{array}$ \\
\hline
\end{tabular}


Table 1 continued

\begin{tabular}{|c|c|c|c|c|c|c|c|}
\hline Study & Ref & $n$ & $\begin{array}{l}\text { Follow- } \\
\text { up } \\
\text { (weeks) }\end{array}$ & Baseline treatment & $\begin{array}{l}\text { Comparator } \\
\text { drug }\end{array}$ & $\begin{array}{l}\text { Dosage of } \\
\text { semaglutide }\end{array}$ & Major findings \\
\hline $\begin{array}{l}\text { PIONEER- } \\
4\end{array}$ & 15 & 711 & 52 & $\begin{array}{l}\text { Metformin with or } \\
\text { without a SGLT- } \\
2 \text { inhibitor }\end{array}$ & $\begin{array}{l}\text { Liraglutide } \\
\text { (dose } \\
\text { escalated to } \\
1.8 \mathrm{mg} / \text { day) }\end{array}$ & $\begin{array}{l}\text { Up to } \\
14 \mathrm{mg} / \text { day }\end{array}$ & $\begin{array}{l}\text { Semaglutide reduced } \mathrm{HbA}_{1 \mathrm{c}} \text { by } \\
0.2 \text { and } 1.2 \% \text { more than } \\
\text { liraglutide and placebo, } \\
\text { respectively, and body } \\
\text { weight by } 1.5 \text { and } 4.0 \mathrm{~kg} \\
\text { more than liraglutide and } \\
\text { placebo, respectively } \\
\text { Rates of adverse events were } \\
\text { similar in the semaglutide } \\
\text { and liraglutide group and } \\
\text { lower in the placebo group }\end{array}$ \\
\hline $\begin{array}{l}\text { PIONEER- } \\
5^{\mathrm{a}}\end{array}$ & 19 & 324 & 26 & $\begin{array}{l}\text { Metformin or } \\
\text { sulfonylurea, or } \\
\text { both, or basal } \\
\text { insulin with or } \\
\text { without } \\
\text { metformin }\end{array}$ & & $\begin{array}{l}\text { Up to } \\
14 \mathrm{mg} / \text { day }\end{array}$ & $\begin{array}{l}\text { Semaglutide reduced } \mathrm{HbA}_{1 \mathrm{c}} \\
\text { and weight by } 1.1 \% \text { and } \\
3.7 \mathrm{~kg} \text { more than placebo, } \\
\text { respectively } \\
\text { Treatment discontinuation } \\
\text { due to adverse events: } 15 \text { and } \\
5 \% \text {, respectively }\end{array}$ \\
\hline $\begin{array}{l}\text { PIONEER- } \\
9^{\mathrm{b}}\end{array}$ & 20 & 243 & 52 & & $\begin{array}{l}\text { Liraglutide } \\
0.75 \mathrm{mg} / \text { day }\end{array}$ & $14 \mathrm{mg} /$ day & $\begin{array}{l}\text { Semaglutide and liraglutide } \\
\text { induced similar reductions } \\
\text { in } \mathrm{HbA}_{1 \mathrm{c}}(1.7 \text { and } 1.4 \% \text {, } \\
\text { respectively) } \\
\text { Constipation, which was the } \\
\text { most frequent adverse event, } \\
\text { occurred in } 13 \text { and } 19 \% \text { of } \\
\text { patients, respectively }\end{array}$ \\
\hline
\end{tabular}


Table 1 continued

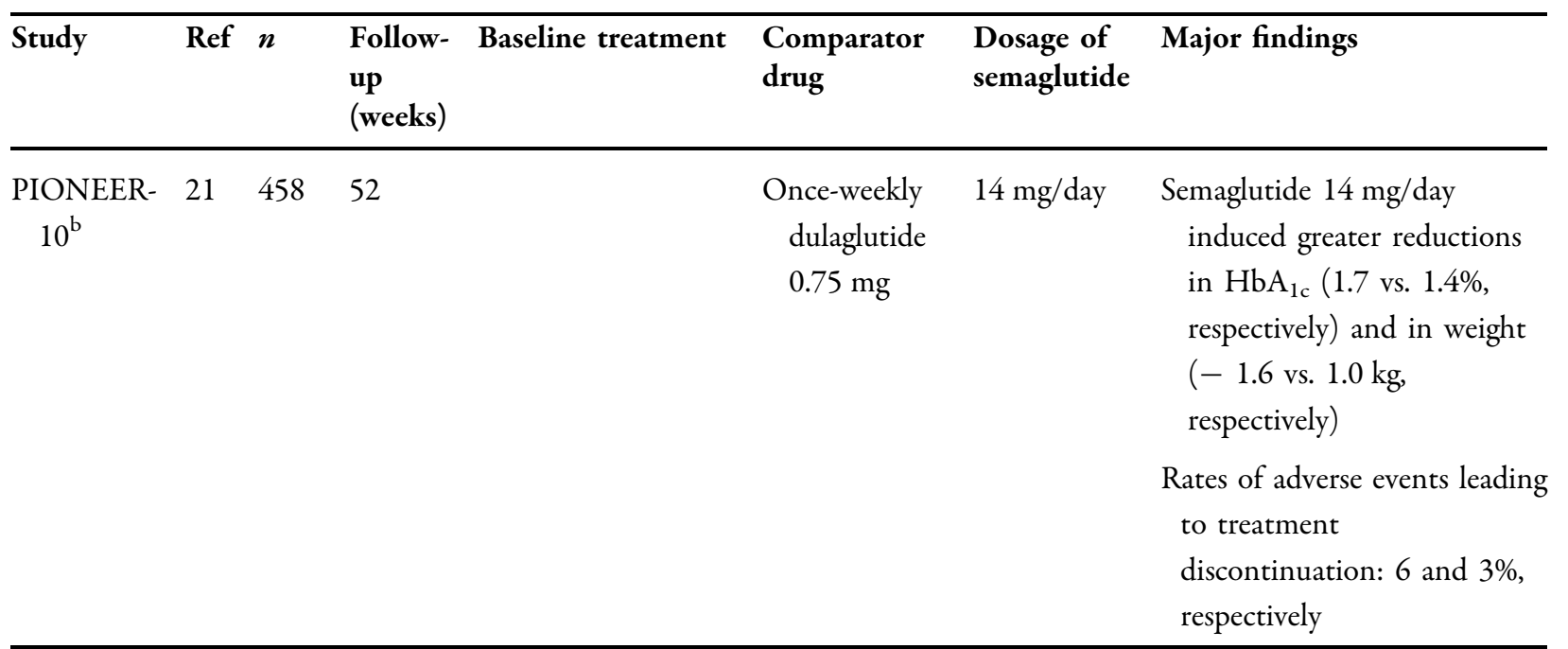

PIONEER Peptide InnOvatioN for Early DiabEtes Treatment, T2DM type 2 diabetes mellitus, SGLT sodium-glucose cotransporter

a Patients had moderate renal impairment (estimated glomerular filtration rate $30-59 \mathrm{ml} / \mathrm{min} / 1.73 \mathrm{~m}^{2}$

b Study performed in Japanese patients

Semaglutide induced dose-dependent reductions in $\mathrm{HbA}_{1 \mathrm{c}}$ (by $0.7,1.2$ and $1.4 \%$ more than placebo, respectively) and in body weight (by $0.2,1.0$ and $2.6 \mathrm{~kg}$ more than placebo, respectively) [13]. Nausea and diarrhea were the most common adverse events in patients treated with semaglutide and resulted in treatment discontinuation in $2.3,4.0$ and $7.4 \%$ of patients, respectively, compared with $2.2 \%$ in patients treated with placebo [13].

In the PIONEER-8 study, 731 patients with T2DM uncontrolled on insulin with or without metformin were randomized to receive oral semaglutide 3,7 or $14 \mathrm{mg} /$ day or placebo for 52 weeks [14]. Semaglutide yielded dose-dependent reductions in $\operatorname{HbA}_{1 \mathrm{c}}(0.5,0.9$ and $1.2 \%$ more than placebo) and in body weight $(0.9,2.0$ and $3.3 \mathrm{~kg}$ more than placebo) [14]. However, the incidence of nausea was also dose-dependently higher in patients treated with semaglutide (1.6-3.3 times higher) [14].

\section{Oral Semaglutide Compared with Other Oral Antidiabetic Agents}

In the PIONEER-7 study, 504 patients with T2DM uncontrolled on 1-2 oral antidiabetic agents were randomized to receive oral semaglutide with flexible dose adjustments to 3 , 7 or $14 \mathrm{mg} /$ day or sitagliptin $100 \mathrm{mg} /$ day for 52 weeks [15]. The proportion of patients who achieved $\mathrm{HbA}_{1 \mathrm{c}}$ levels $<7 \%$ was greater in the semaglutide group (63 vs. $28 \%$ in the sitagliptin group), and mean weight loss was $2.2 \mathrm{~kg}$ greater in the former [15].

In the PIONEER-3 study, 1864 patients with T2DM uncontrolled with metformin with or without sulfonylurea were randomized to receive once-daily oral semaglutide 3,7 or $14 \mathrm{mg}$ or sitagliptin $100 \mathrm{mg} /$ day for 78 weeks [16]. Semaglutide induced dose-dependent reductions in $\mathrm{HbA}_{1 \mathrm{c}}$ and at the dose of 7 and $14 \mathrm{mg} /$ day was more effective in reducing $\mathrm{HbA}_{1 \mathrm{c}}$ than sitagliptin (difference, 0.3 and $0.7 \%$, respectively) [16]. Semaglutide also induced dose-dependent reductions in body 
weight that were greater than those of sitagliptin at 78 weeks in all semaglutide doses (difference, $0.8,1.6$ and $2.4 \mathrm{~kg}$ with the 3,7 or $14 \mathrm{mg} /$ day dose, respectively) [16]. Treatment discontinuation rates in the semaglutide 3,7 or $14 \mathrm{mg}$ and sitagliptin groups were 16.7, 15.0, 19.1 and $13.1 \%$, respectively [16].

In the PIONEER-2 study, 822 patients with T2DM uncontrolled on metformin were randomized to receive oral semaglutide $14 \mathrm{mg}$ /day or empagliflozin $25 \mathrm{mg} /$ day for 52 weeks [17]. Semaglutide reduced $\mathrm{HbA}_{1 \mathrm{c}}$ and body weight more than empaglifozin (mean treatment difference $0.4 \%$ and $0.9 \mathrm{~kg}$, respectively) [17]. On the other hand, gastrointestinal adverse events were more common with oral semaglutide [17].

\section{Oral Semaglutide Compared with Injectable Antidiabetic Agents}

In the PIONEER-4 study, 711 patients with T2DM uncontrolled despite treatment with metformin ( $\geq 1500 \mathrm{mg} /$ day or maximum tolerated dose) with or without a sodium-glucose cotransporter- 2 inhibitor were randomized to receive once-daily oral semaglutide (dose escalated to $14 \mathrm{mg}$ ), once-daily subcutaneous liraglutide (dose escalated to $1.8 \mathrm{mg}$ ) or placebo for 52 weeks [18]. Semaglutide reduced $\mathrm{HbA}_{1 \mathrm{c}}$ by 0.2 and $1.2 \%$ more than liraglutide and placebo, respectively, and also reduced body weight by 1.5 and $4.0 \mathrm{~kg}$ more than liraglutide and placebo, respectively [18]. Rates of adverse events were similar in the semaglutide and liraglutide group and lower in the placebo group [18].

\section{Oral Semaglutide in Special Populations}

Studies in special populations yielded similar results. In PIONEER-5, 324 patients with T2DM and moderate renal impairment (estimated GFR $30-59 \mathrm{ml} / \mathrm{min} / 1.73 \mathrm{~m}^{2}$ ) who were receiving metformin or sulfonylurea, or both, or basal insulin with or without metformin, were randomly assigned to receive oral semaglutide (dose escalated to $14 \mathrm{mg}$ once daily) or placebo for 26 weeks [19]. Oral semaglutide reduced $\mathrm{HbA}_{1 \mathrm{c}}$ by $1.1 \%$ and body weight by $3.7 \mathrm{~kg}$ more than placebo [19]. However, treatment discontinuation due to adverse events was three times higher with oral semaglutide ( $15 \%$ vs. $5 \%$ in the placebo group) [19].

In PIONEER-9, a 52-week, randomized trial in 243 Japanese patients with T2DM, oral semaglutide $14 \mathrm{mg} /$ day induced similar reductions in $\mathrm{HbA}_{1 \mathrm{c}}$ with once-daily liraglutide $0.75 \mathrm{mg}$ (1.7 vs. 1.4 percentage points, respectively) [20]. On the other hand, the incidence of constipation, which was the most frequent adverse event, was lower in the semaglutide group (13 vs. 19\% in the liraglutide group) [20].

In PIONEER-10, a 52-week randomized trial in 458 Japanese patients with T2DM, oral semaglutide $14 \mathrm{mg} /$ day induced greater reductions in $\mathrm{HbA}_{1 \mathrm{c}}$ than once-weekly dulaglutide $0.75 \mathrm{mg}$ (1.7 vs. 1.4 percentage points, respectively) and in body weight (- $1.6 \mathrm{vs} .1 .0 \mathrm{~kg}$, respectively) [21]. However, the rate of adverse events leading to discontinuation of treatment was two times higher in the semaglutide group (6 vs. $3 \%$ in the dulaglutide group) [21].

\section{Meta-Analyses of the Safety and Efficacy of Oral Semaglutide}

In a network meta-analysis of 27 randomized controlled studies, oral semaglutide $14 \mathrm{mg} /$ day induced greater reductions in $\mathrm{HbA}_{1 \mathrm{c}}$ than onceweekly dulaglutide $0.75 \mathrm{mg}$, twice-daily exenatide, once-weekly exenatide $2 \mathrm{mg}$, liraglutide $1.2 \mathrm{mg}$ and lixisenatide [22]. In addition, oral semaglutide yielded similar reductions in $\mathrm{HbA}_{1 \mathrm{c}}$ with once-weekly semaglutide, once-weekly dulaglutide $1.5 \mathrm{mg}$ and liraglutide $1.8 \mathrm{mg}$ [22]. Moreover, oral semaglutide $14 \mathrm{mg}$ /day induced similar weight loss with once-weekly semaglutide and greater than all other GLP-1 receptor agonists [22]. Oral semaglutide $14 \mathrm{mg} /$ day also induced similar reductions in systolic and diastolic blood pressure with all other GLP-1 receptor agonists except once-weekly semaglutide $1.0 \mathrm{mg}$, which induced greater reductions in systolic blood pressure (SBP) [22]. The incidence of gastrointestinal adverse events did not differ between the various GLP-1 receptor agonists [22]. 


\section{EFFECTS OF ORAL SEMAGLUTIDE ON CARDIOVASCULAR MORBIDITY AND MORTALITY}

The effects of oral semaglutide on cardiovascular events was evaluated in the PIONEER- 6 trial, a randomized placebo-controlled trial in 3183 patients with T2DM who were $\geq 50$ years old and had established CVD or chronic kidney disease or were $\geq 60$ years with cardiovascular risk factors only [23]. The trial was designed to rule out an $80 \%$ excess cardiovascular risk compared with placebo [noninferiority margin of 1.8 for the upper boundary of the $95 \%$ confidence interval (CI) for the hazard ratio (HR) for the primary outcome] [23]. After a median follow-up of 15.9 months, the incidence of the primary outcome (the first occurrence of a major adverse cardiovascular event, i.e., death from cardiovascular causes, nonfatal myocardial infarction or nonfatal stroke) did not differ between the groups assigned to receive semaglutide or placebo (3.8 vs. $4.8 \%$, respectively; HR $0.79,95 \%$ CI $0.57-1.11, p<0.001$ for noninferiority) [23]. Notably, rates of death from cardiovascular causes were lower in patients treated with oral semaglutide (0.9 vs. $1.9 \%$ in the placebo group, HR $0.49,95 \%$ CI $0.27-0.92)$, and rates of death from any cause were also lower in the former $(1.4$ vs. $2.8 \%$ in the placebo group, HR $0.51,95 \%$ CI $0.31-0.84$ ) [23]. Semaglutide reduced $\mathrm{HbA}_{1 \mathrm{c}}$ by $0.7 \%$ more than placebo and body weight by $3.4 \mathrm{~kg}$ more than placebo [23]. In addition, the reductions in systolic blood pressure (SBP), low-density lipoprotein cholesterol and triglyceride levels were greater in the former [23]. On the other hand, rates of treatment discontinuation were higher in the semaglutide group (11.6 vs. $6.5 \%$ in the placebo group), primarily because of nausea, vomiting and diarrhea [23]. In PIONEER-6, when patients with established CVD or established heart failure were analyzed separately, there was no effect of semaglutide on the incidence of major adverse cardiovascular events, i.e., cardiovascular death and nonfatal myocardial infarction or stroke [24]. Similarly, semaglutide had no effect on cardiovascular morbidity in patients without established CVD or heart failure [24]. Interestingly, in a recent network meta-analysis of seven trials in 56,004 patients, oral semaglutide reduced cardiovascular mortality more than exenatide, dulaglutide and lixisenatide and was similarly effective with liraglutide and once-weekly injectable semaglutide [25].

\section{COST-EFFECTIVENESS OF ORAL SEMAGLUTIDE}

In a recent cost-effectiveness analysis, oral semaglutide $14 \mathrm{mg} /$ day was associated with lower cost for achieving $\mathrm{HbA}_{1 \mathrm{c}}$ levels $<6.5 \%$ or $<7.0 \%$ than dulaglutide, exenatide (once weekly and twice daily), liraglutide and lixisenatide, whereas once-weekly semaglutide $1.0 \mathrm{mg}$ had comparable cost [26]. In a similar study, oral semaglutide $14 \mathrm{mg}$ /day was associated with lower cost for achieving $\mathrm{HbA}_{1 \mathrm{c}}$ levels $<6.5 \%$ or $<7.0 \%$, for achieving $\geq 1.0 \%$ point $\mathrm{HbA}_{1 \mathrm{c}}$ reduction and weight loss $\geq 3.0 \%$ and for achieving $\mathrm{HbA}_{1 \mathrm{c}}$ levels $<7.0 \%$ without hypoglycemia and without weight gain than empagliflozin, sitagliptin and liraglutide [27]. In another recent cost-effectiveness analysis, oral semaglutide $14 \mathrm{mg} /$ day was more cost-effective than empagliflozin and sitagliptin and was also both more effective and less expensive than liraglutide [28].

\section{ORAL VERSUS INJECTABLE SEMAGLUTIDE}

Even though there are no studies that directly compared oral and injectable semaglutide, a network meta-analysis suggested that these two formulations of semaglutide have comparable safety and induce similar reductions in $\mathrm{HbA}_{1 \mathrm{c}}$ and body weight [22]. However, once-weekly injectable semaglutide induces greater reductions in SBP than oral semaglutide [22]. Moreover, in the Trial to Evaluate Cardiovascular and Other Long-term Outcomes with Semaglutide in Subjects with Type 2 Diabetes (SUSTAIN-6), once-weekly semaglutide reduced the incidence of the primary endpoint (the first occurrence of cardiovascular death, nonfatal myocardial 
infarction, or nonfatal stroke) by $26 \%$ compared with placebo in a population with similar size $(n=3297)$ and characteristics as the PIONEER-6 trial [3]. However, the follow-up period of SUSTAIN-6 was longer than in PIONEER-6 (24 vs. 15.9 months, respectively), and this might have contributed to the different results of the two studies [3, 23]. In addition, once-weekly semaglutide did not reduce cardiovascular or all-cause mortality in contrast to oral semaglutide, which reduced the incidence of both these outcomes [3, 23]. In a network meta-analysis, oral and once-weekly injectable semaglutide yielded similar reductions in cardiovascular mortality [25]. Cost-effectiveness of these two formulations also appears to be comparable [26]. Given the similar safety, efficacy and costeffectiveness of oral and injectable semaglutide, the choice between the two formulations should be based on patients' preferences (oral vs. once weekly administration).

\section{CONCLUSIONS}

Oral semaglutide appears to be more effective in reducing $\mathrm{HbA}_{1 \mathrm{c}}$ levels and body weight than other antidiabetic agents and similarly effective as other GLP-1 receptor agonists. The safety profile of oral semaglutide is also comparable to other members of its class. Even though oral semaglutide did not reduce the incidence of the composite primary endpoint in the PIONEER-6 trial, a reduction in cardiovascular and all-cause mortality was observed. Therefore, oral semaglutide appears to represent a useful tool in the management of patients with TD2M, particularly those with established CVD or high cardiovascular risk and unwilling to receive injectable GLP-1 receptor agonists. Future studies should further evaluate the effects of oral semaglutide on both cardiovascular events and the microvascular complications of T2DM. In addition, studies in specific subgroups, including those with and without established cardiovascular disease as well as in those with diabetic nephropathy, will add new insights into the role of this agent in the management of T2DM.

\section{ACKNOWLEDGEMENTS}

Funding. No funding or sponsorship was received for this study or publication of this article.

Authorship. All named authors meet the International Committee of Medical Journal Editors (ICMJE) criteria for authorship for this article, take responsibility for the integrity of the work as a whole, and have given their approval for this version to be published.

Disclosures. Areti Sofogianni and Konstantinos Tziomalos have nothing to disclose.

Compliance with Ethics Guidelines. This article is based on previously conducted studies and does not contain any studies with human participants or animals performed by any of the authors.

Data Availability. Data sharing is not applicable to this article as no datasets were generated or analyzed during the current study.

Open Access. This article is licensed under a Creative Commons Attribution-NonCommercial 4.0 International License, which permits any non-commercial use, sharing, adaptation, distribution and reproduction in any medium or format, as long as you give appropriate credit to the original author(s) and the source, provide a link to the Creative Commons licence, and indicate if changes were made. The images or other third party material in this article are included in the article's Creative Commons licence, unless indicated otherwise in a credit line to the material. If material is not included in the article's Creative Commons licence and your intended use is not permitted by statutory regulation or exceeds the permitted use, you will need to obtain permission directly from the copyright holder. To view a copy of this licence, visit http://creativecommons.org/licenses/bync/4.0/. 


\section{REFERENCES}

1. Buse JB, Wexler DJ, Tsapas A, et al. Update to: management of hyperglycaemia in type 2 diabetes, 2018. A consensus report by the American Diabetes Association (ADA) and the European Association for the Study of Diabetes (EASD). Diabetologia. 2019;(63):221-8.

2. Marso SP, Daniels GH, Brown-Frandsen K, LEADER Steering Committee, LEADER Trial Investigators, et al. Liraglutide and cardiovascular outcomes in type 2 diabetes. N Engl J Med. 2016;375:311-22.

3. Marso SP, Bain SC, Consoli A, SUSTAIN-6 Investigators, et al. Semaglutide and cardiovascular outcomes in patients with type 2 diabetes. $\mathrm{N}$ Engl J Med. 2016;375:1834-44.

4. Gerstein HC, Colhoun HM, Dagenais GR, REWIND Investigators, et al. Dulaglutide and cardiovascular outcomes in type 2 diabetes (REWIND): a doubleblind, randomized placebo-controlled trial. Lancet. 2019;394:121-30.

5. Buckley ST, Bækdal TA, Vegge A, et al. Transcellular stomach absorption of a derivatized glucagon-like peptide-1 receptor agonist. Sci Transl Med. 2018;10: eaar7047.

6. Twarog C, Fattah S, Heade J, Maher S, Fattal E, Brayden DJ. Intestinal permeation enhancers for oral delivery of macromolecules: a comparison between salcaprozate sodium (SNAC) and sodium caprate (C10). Pharmaceutics. 2019;11:78.

7. Riley MG, Castelli MC, Paehler EA. Subchronic oral toxicity of salcaprozate sodium (SNAC) in SpragueDawley and Wistar rats. Int J Toxicol. 2009;28: 278-93.

8. Brayden DJ, Hill TA, Fairlie DP, Maher S, Mrsny RJ. Systemic delivery of peptides by the oral route: formulation and medicinal chemistry approaches. Adv Drug Deliv Rev. 2020. https://doi.org/10.1016/ j.addr.2020.05.007.

9. Bækdal TA, Borregaard J, Hansen CW, Thomsen M, Anderson TW. Effect of oral semaglutide on the pharmacokinetics of lisinopril, warfarin, digoxin, and metformin in healthy subjects. Clin Pharmacokinet. 2019;58:1193-203.

10. Bækdal TA, Breitschaft A, Navarria A, Hansen CW. A randomized study investigating the effect of omeprazole on the pharmacokinetics of oral semaglutide. Expert Opin Drug Metab Toxicol. 2018;14:869-77.

11. Baekdal TA, Thomsen M, Kupčová V, Hansen CW, Anderson TW. Pharmacokinetics, safety, and tolerability of oral semaglutide in subjects with hepatic impairment. J Clin Pharmacol. 2018;58: 1314-23.

12. Granhall C, Søndergaard FL, Thomsen M, Anderson TW. Pharmacokinetics, safety and tolerability of oral semaglutide in subjects with renal impairment. Clin Pharmacokinet. 2018;57:1571-80.

13. Aroda VR, Rosenstock J, Terauchi Y, PIONEER 1 Investigators, et al. PIONEER 1: randomized clinical trial of the efficacy and safety of oral semaglutide monotherapy in comparison with placebo in patients with type 2 diabetes. Diabetes Care. 2019;42:1724-32.

14. Pratley R, Amod A, Hoff ST, PIONEER 4 investigators, et al. Oral semaglutide versus subcutaneous liraglutide and placebo in type 2 diabetes (PIONEER 4): a randomised, double-blind, phase 3a trial. Lancet. 2019;394:39-50.

15. Zinman B, Aroda VR, Buse JB, PIONEER 8 Investigators, et al. Efficacy, safety, and tolerability of oral semaglutide versus placebo added to insulin with or without metformin in patients with type 2 diabetes: the PIONEER 8 trial. Diabetes Care. 2019;42: 2262-71.

16. Rosenstock J, Allison D, Birkenfeld AL, PIONEER 3 Investigators, et al. Effect of additional oral semaglutide vs sitagliptin on glycated hemoglobin in adults with type 2 diabetes uncontrolled with metformin alone or with sulfonylurea: the PIONEER 3 randomized clinical trial. JAMA. 2019;321: 1466-80.

17. Rodbard HW, Rosenstock J, Canani LH, PIONEER 2 Investigators, et al. Oral semaglutide versus empagliflozin in patients with type 2 diabetes uncontrolled on metformin: the PIONEER 2 trial. Diabetes Care. 2019;42:2272-81.

18. Pieber TR, Bode B, Mertens A, PIONEER 7 investigators, et al. Efficacy and safety of oral semaglutide with flexible dose adjustment versus sitagliptin in type 2 diabetes (PIONEER 7): a multicentre, openlabel, randomised, phase 3 a trial. Lancet Diabetes Endocrinol. 2019;7:528-39.

19. Mosenzon O, Blicher TM, Rosenlund S, PIONEER 5 Investigators, et al. Efficacy and safety of oral semaglutide in patients with type 2 diabetes and moderate renal impairment (PIONEER 5): a placebo-controlled, randomised, phase 3 a trial. Lancet Diabetes Endocrinol. 2019;7:515-27.

20. Yamada $\mathrm{Y}$, Katagiri H, Hamamoto Y, PIONEER 9 investigators, et al. Dose-response, efficacy, and safety of oral semaglutide monotherapy in Japanese patients with type 2 diabetes (PIONEER 9): a 
52-week, phase 2/3a, randomised, controlled trial. Lancet Diabetes Endocrinol. 2020;8:377-91.

21. Yabe D, Nakamura J, Kaneto H, PIONEER 10 Investigators, et al. Safety and efficacy of oral semaglutide versus dulaglutide in Japanese patients with type 2 diabetes (PIONEER 10): an open-label, randomised, active-controlled, phase $3 \mathrm{a}$ trial. Lancet Diabetes Endocrinol. 2020;8:392-406.

22. Nuhoho S, Gupta J, Hansen BB, Fletcher-Louis M, Dang-Tan T, Paine A. Orally administered semaglutide versus GLP-1 RAs in patients with type 2 diabetes previously receiving 1-2 oral antidiabetics: systematic review and network meta-analysis. Diabetes Ther. 2019;10:2183-99.

23. Husain M, Birkenfeld AL, Donsmark M, PIONEER 6 Investigators, et al. Oral semaglutide and cardiovascular outcomes in patients with type 2 diabetes. N Engl J Med. 2019;381:841-51.

24. Husain M, Bain SC, Jeppesen OK, et al. Semaglutide (SUSTAIN and PIONEER) reduces cardiovascular events in type 2 diabetes across varying cardiovascular risk. Diabetes Obes Metab. 2020;22:442-51.
25. Alfayez OM, Almohammed OA, Alkhezi OS, Almutairi AR, Al Yami MS. Indirect comparison of glucagon like peptide-1 receptor agonists regarding cardiovascular safety and mortality in patients with type 2 diabetes mellitus: network meta-analysis. Cardiovasc Diabetol. 2020;19:96.

26. Hansen BB, Nuhoho S, Ali SN, et al. Oral semaglutide versus injectable glucagon-like peptide-1 receptor agonists: a cost of control analysis. J Med Econ. 2020;23:650-8.

27. Hunt B, Hansen BB, Ericsson $\AA$, et al. Evaluation of the cost per patient achieving treatment targets with oral semaglutide: a short-term cost-effectiveness analysis in the United States. Adv Ther. 2019;36:3483-93.

28. Bain SC, Hansen BB, Malkin SJP, et al. Oral semaglutide versus empagliflozin, sitagliptin and liraglutide in the UK: long-term cost-effectiveness analyses based on the PIONEER clinical trial programme. Diabetes Ther. 2020;11:259-77. 